\title{
Wpływ procesów transformacji na rozwój małych firm prywatnych w Polsce
}

\begin{abstract}
Wstęp
W końcu lat osiemdziesiątych XX w. rozpoczęła się w Polsce transformacja systemu społeczno-ekonomicznego. W tym procesie uległy przemianom struktury polityczne, społeczne, gospodarcze i przestrzenne. Szczególnie widoczny jest wpływ transformacji na przeobrażenia struktury wielkościowej i własnościowej podmiotów gospodarczych, czego skutkiem był dynamiczny rozwój małych prywatnych przedsiębiorstw i zdecydowany wzrost ich znaczenia w strukturze pracujaccych w gospodarce narodowej z 7,9\% w 1988 r. do 23,8\% w 2004 r.

Proces przekształceń struktury własnościowej i wielkościowej podmiotów gospodarczych przebiegał z różnym natężeniem w czasie i przestrzeni. Poszczególne obszary odznaczały się odmienną podatnością na przyjmowanie nowych zasad gospodarowania, pojawiły się więc znaczne różnice $\mathrm{w}$ rozmieszczeniu i strukturze rodzajowej małych firm prywatnych. Na tym tle rodzą się pytania:

1. Jakie są prawidłowości rozwoju i przemian struktury przestrzennej małych firm prywatnych w Polsce w okresie transformacji?

2. Jakie sa prawidłowości przemian struktury rodzajowej małych firm prywatnych w Polsce w okresie transformacji?

3. Jakie czynniki wpływają na rozwój małych firm prywatnych w Polsce w okresie transformacji?
\end{abstract}

Odpowiedzi na te pytania są celem niniejszego artykułu.

\section{Zakres badań i źródła informacji}

Zakres przestrzenny badań obejmuje całą Polskę w podziale na rejony urzędów skarbowych. Badania ograniczono do małych firm prywatnych prowadzonych przez osoby fizyczne. W 2004 r. stanowiły one $96 \%$ ogółu podmiotów gospodarczych w kraju. Podstawowym przyjętym do analizy miernikiem była liczba zakładów, co wynikało z dostępności danych. Jak wykazują badania (Kamińska 2004), firmy te należą do mikroprzedsiębiorstw: średnia liczba pracujących wynosi w nich około 2 osób. Zatem przyjęcie wskazanego wyżej miernika nie wpłynie zasadniczo na wnioski wynikające z badań. Analizę oparto na danych za lata 1988-2004, uzyskanych ze wszystkich urzędów skarbowych w Polsce.

Badaniami objęto zakłady zarejestrowane w urzędach podatkowych, a rozwój małych firm prywatnych rozpatrzono w latach 1989-2004. Rok 1988 przyjęto jako ostatni rok funkcjonowania systemu sterowanego centralnie. 


\section{Małe firmy prywatne w Polsce w okresie centralnego sterowania}

W okresie centralnego sterowania polityka rządu wobec sektora prywatnego w Polsce była na ogół restrykcyjna. Dostrzegano rolę prywatnej działalności w łagodzeniu napięć na rynku, jednak względy ideologiczne były zdecydowanie ważniejsze aniżeli ekonomiczne i społeczne. W konsekwencji potencjał sektora prywatnego był nieduży.

W 1988 r. funkcjonowało 624,4 tys. małych firm prywatnych, w których pracowało 1125,4 tys. osób. W stosunku do ogółu pracujących w gospodarce narodowej poza rolnictwem stanowiło to zaledwie 7,9\%. Wskaźnik przedsiębiorczości obrazujący liczbę małych firm prywatnych na 1000 mieszkańców wynosił 16.

W 1988 r. regionalne różnice między poszczególnymi jednostkami nie były zbyt wysokie (ryc. 1). Wynikało to z centralnej reglamentacji zezwoleń na prowadzenie działalności gospodarczej w sektorze prywatnym. Pomimo niewielkiego regionalnego zróżnicowania wskaźnika przedsiębiorczości w układzie przestrzennym, można sformułować następujące prawidłowości:

1. Najwyższe wskaźniki przedsiębiorczości wystąpiły w rejonach położonych w najbliższym sąsiedztwie Warszawy: w Otwocku (36,3), Wołominie (35,6), Pruszkowie $(31,6)$, Piasecznie $(24,4)$. Wskaźniki te były wyższe niż w samej stolicy.

2. Wysokie wskaźniki przedsiębiorczości (wyższe od średniej krajowej) wystapiły w niektórych rejonach związanych z wielkimi miastami: w Poznaniu $(29,8)$, Łodzi $(25,9)$ i Warszawie $(21,4)$.

3. Stosunkowo wysokie wskaźniki przedsiębiorczości zanotowano w rejonach nadmorskich (w kołobrzeskim 25,6, w sopockim 26,8) oraz górskich (w nowotarskim 23,7, w zakopiańskim 23,7). Wynikało to z atrakcyjności turystycznej tych obszarów. Napływ turystów, zwłaszcza w sezonie letnim, wpływał na powstawanie zakładów osób fizycznych związanych z szeroko rozumianą obsługą ruchu turystycznego (np. wynajem pokoi, mała gastronomia, sprzedaż pamiątek).

4. Wartości wskaźnika przedsiębiorczości wzrastały w miarę przesuwania się ze wschodu kraju na zachód. Widoczne przy tym były „wyspy”, związane najczęściej z dużymi miastami, gdzie liczba zakładów na 1000 mieszkańców była wyższa niż na obszarach przyległych.

W 1988 r. największe znaczenie miały zakłady rzemieślnicze, które stanowiły 58,6\% ogółu małych firm. Drugą pozycję obejmowały zakłady usługowe skupiające 27,7\% zakładów. Zakłady handlowe stanowiły 13,7\% podmiotów osób fizycznych (tab. 1).

Tab. 1. Struktura rodzajowa pozarolniczej indywidualnej działalności gospodarczej w Polsce w 1988 r.

\begin{tabular}{|l|c|c|c|c|c|}
\hline \multirow{2}{*}{ Dzial } & \multirow{2}{*}{$\begin{array}{c}\text { Liczba } \\
\text { zakładów }\end{array}$} & \multirow{2}{*}{$\begin{array}{c}\text { Liczba } \\
\text { pracujących }\end{array}$} & \multicolumn{2}{c|}{ Struktura (w \%) } & \multirow{2}{*}{$\begin{array}{c}\text { Średnie } \\
\text { zatrudnienie }\end{array}$} \\
\cline { 4 - 5 } & & zakładów & pracujących & \\
\hline Rzemiosło & 365647 & 808341 & 58,6 & 71,8 & 2,2 \\
\hline Handel & 85590 & 117722 & 13,7 & 10,5 & 1,4 \\
\hline Usługi & 173183 & 199379 & 27,7 & 17,7 & 1,1 \\
\hline Razem & $\mathbf{6 2 4} \mathbf{4 2 0}$ & $\mathbf{1 1 2 5} \mathbf{4 4 2}$ & $\mathbf{1 0 0 , 0}$ & $\mathbf{1 0 0 , 0}$ & $\mathbf{1 , 8}$ \\
\hline
\end{tabular}

Źródło: obliczenia własne na podstawie sprawozdań MF-2PS urzędów skarbowych w Polsce za 1988 r.

Struktura rodzajowa małych firm prywatnych w układzie przestrzennym była podobna. Dowodzi to, że rozwijała się ona pod wpływem tych samych czynników. Były to głównie czynniki o charakterze administracyjnym (reglamentacja zezwoleń na prowadzenie działalności gospodarczej). 
Ryc. 1. Zróżnicowanie przestrzenne wskaźnika przedsiębiorczości w Polsce w 1988 r.

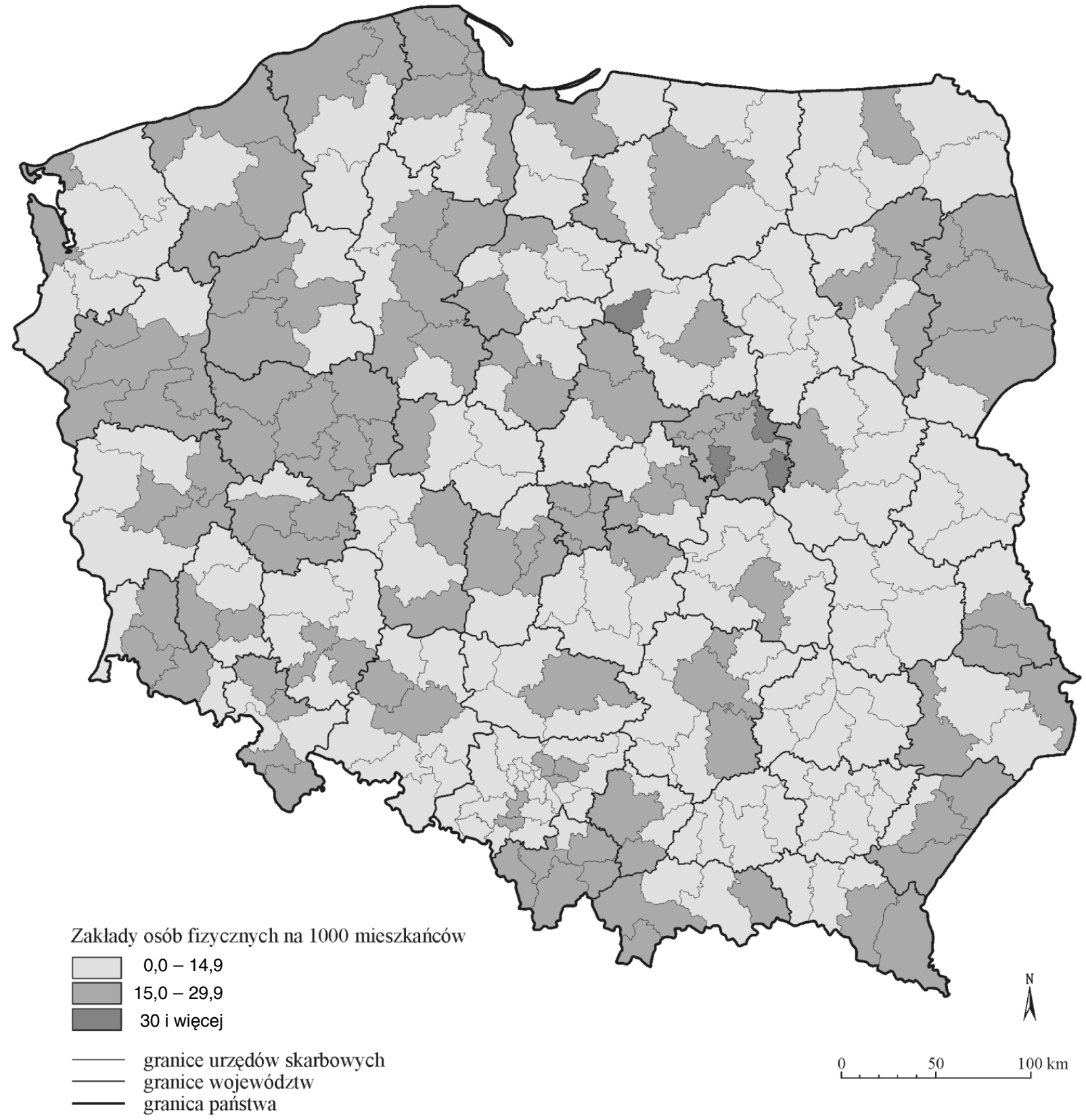

Rozwój małych firm prywatnych w Polsce w okresie transformacji gospodarki narodowej

W latach 1988-2004 liczba małych firm prywatnych wzrosła z 624,4 tys. do 2557,0 tys., tj. do $409,5 \%$ (tab. 2 , ryc. 2 ).

Tab. 2. Zmiany liczby małych firm prywatnych w Polsce w latach 1988-2004

\begin{tabular}{|c|c|c|c|}
\hline Rok & $\begin{array}{c}\text { Liczba małych firm } \\
\text { prywatnych (w tys.) }\end{array}$ & $\begin{array}{c}\text { Dynamika liczby firm } \\
\mathbf{( 1 9 8 8 = 1 0 0 \% )}\end{array}$ & $\begin{array}{c}\text { Średnia liczba pracują- } \\
\text { cych w zakładzie }\end{array}$ \\
\hline 1988 & 624,4 & 100,0 & 1,80 \\
\hline 1991 & 1418,5 & 227,2 & 1,83 \\
\hline 1998 & 2289,8 & 366,7 & 2,03 \\
\hline $\mathbf{2 0 0 4}$ & $\mathbf{2 ~ 5 5 7 , 0}$ & $\mathbf{4 0 9 , 5}$ & $\mathbf{2 , 0 1}$ \\
\hline
\end{tabular}


Ryc. 2. Zmiany liczby małych firm prywatnych w Polsce w latach 1988-2004

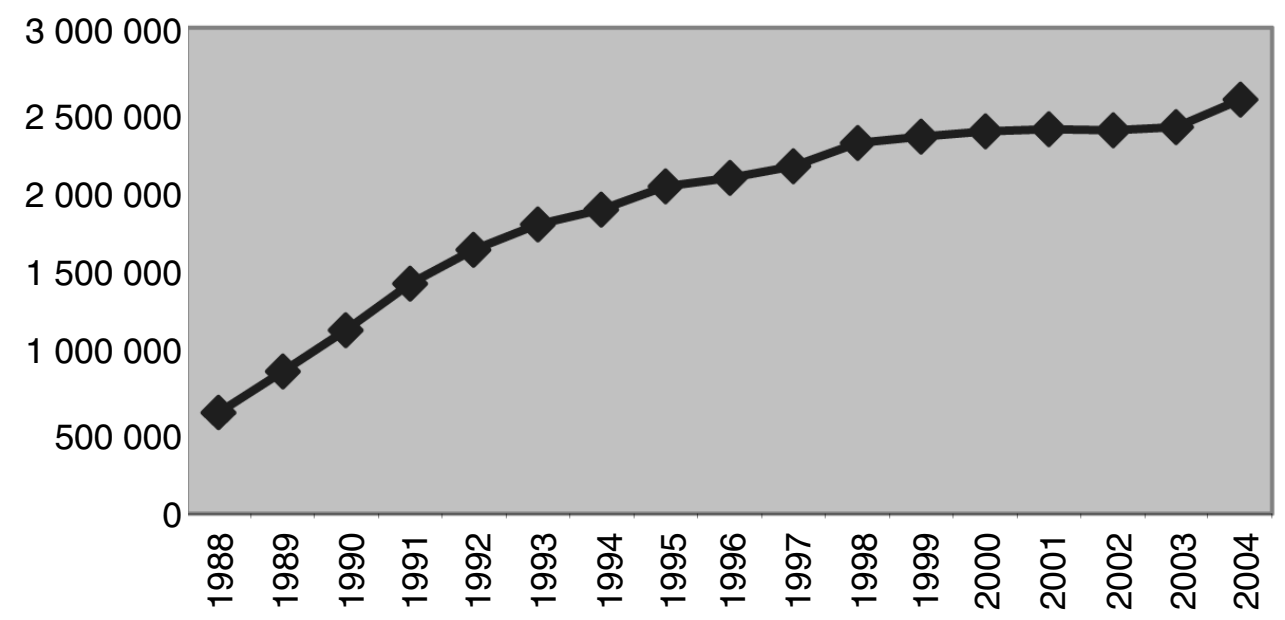

Źródło: opracowanie własne

Przyjmując za kryterium dynamikę liczby zakładów, w tym okresie można wyróżnić dwa podokresy odznaczające się odmiennymi tendencjami.

Pierwszy, związany ze wstępną fazą transformacji, to lata 1988-1991. Liczba małych firm prywatnych wzrosła wówczas z 624,4 tys. do 1418,5 tys., tj. do 227,2\%. Oznacza to, że w ciągu zaledwie 3 lat liczba zakładów podwoiła się. W literaturze ekonomicznej ten okres nazywa się okresem eksplozji przedsiębiorczości (Piasecki 1997, Targalski 1999). Dynamiczny rozwój małych firm prywatnych spowodował wzrost ich znaczenia w gospodarce narodowej. W $1991 \mathrm{r}$. pracujący w tych zakładach stanowili 23,2\% ogółu pracujących w gospodarce narodowej poza rolnictwem. Należy jednak dodać, że ten wzrost tylko po części wynikał z rozwoju przedsiębiorczości; był również związany ze spadkiem liczby pracujących w całej gospodarce narodowej. Do głównych przyczyn tak dynamicznego rozwoju małych firm prywatnych należy zaliczyć: łatwość rejestracji nowych firm, brak miejsc pracy w gospodarce uspołecznionej, wyzwolenie „uśpionej przedsiębiorczości”, niedobory na rynku towarów i usług przy istniejących zasobach finansowych ludności, otwarcie granic państwowych dla przepływu towarów i ludzi, małą konkurencję oraz niskie koszty uruchamiania działalności gospodarczej.

Drugi podokres, związany z zaawansowanym stadium transformacji gospodarki, to lata 1991-2004. Tempo wzrostu prywatnej przedsiębiorczości wyraźnie osłabło w stosunku do lat 1989-1991. Liczba małych firm prywatnych wzrosła z 1418,5 tys. do 2557,0 tys., tj. o 80,3\%. Oznacza to, że średnie roczne tempo wzrostu liczby podmiotów wynosiło 4-6\%. Wzrosła średnia liczba pracujących w zakładzie (z 1,83 w 1991 r. do 2,01 w 2004 r.). W tym okresie pojawiło się wiele barier rozwoju przedsiębiorczości: zmienność i niejasność przepisów prawnych, wysokie obciążenia podatkowe, rosnąca konkurencja krajowa i zagraniczna, rosnące wymagania społeczeństwa co do jakości oraz ceny wyrobów i usług, bariera popytu związana z ubożeniem społeczeństwa i ze zmianą postaw ludności (ograniczenie kupowania na zapas), wysokie koszty zarówno wejścia na rynek, jak i wyjścia z rynku. Te bariery ograniczyły tempo powstawania nowych zakładów i przyspieszyły proces upadania istniejących.

We wszystkich jednostkach przestrzennych liczba małych firm prywatnych wzrosła (ryc. 3). Najwyższymi wskaźnikami wzrostu charakteryzowały się przede wszystkim rejony:

- w których liczba zakładów była stosunkowo niska w roku wyjściowym (np. Krotoszyn, Drawsko, Gryfino, Ostrów Mazowiecka). Wynika to ze sposobu liczenia wskaźnika; 
- w których powstały duże spółki z udziałem kapitału zagranicznego (np. Gliwice, Dębica), ze względu na możliwości kooperacyjne;

- atrakcyjne turystycznie (Wejherowo, Sucha Beskidzka, Puck, Koszalin).

Ryc. 3. Dynamika liczby małych firm prywatnych w Polsce w latach 1988-2004

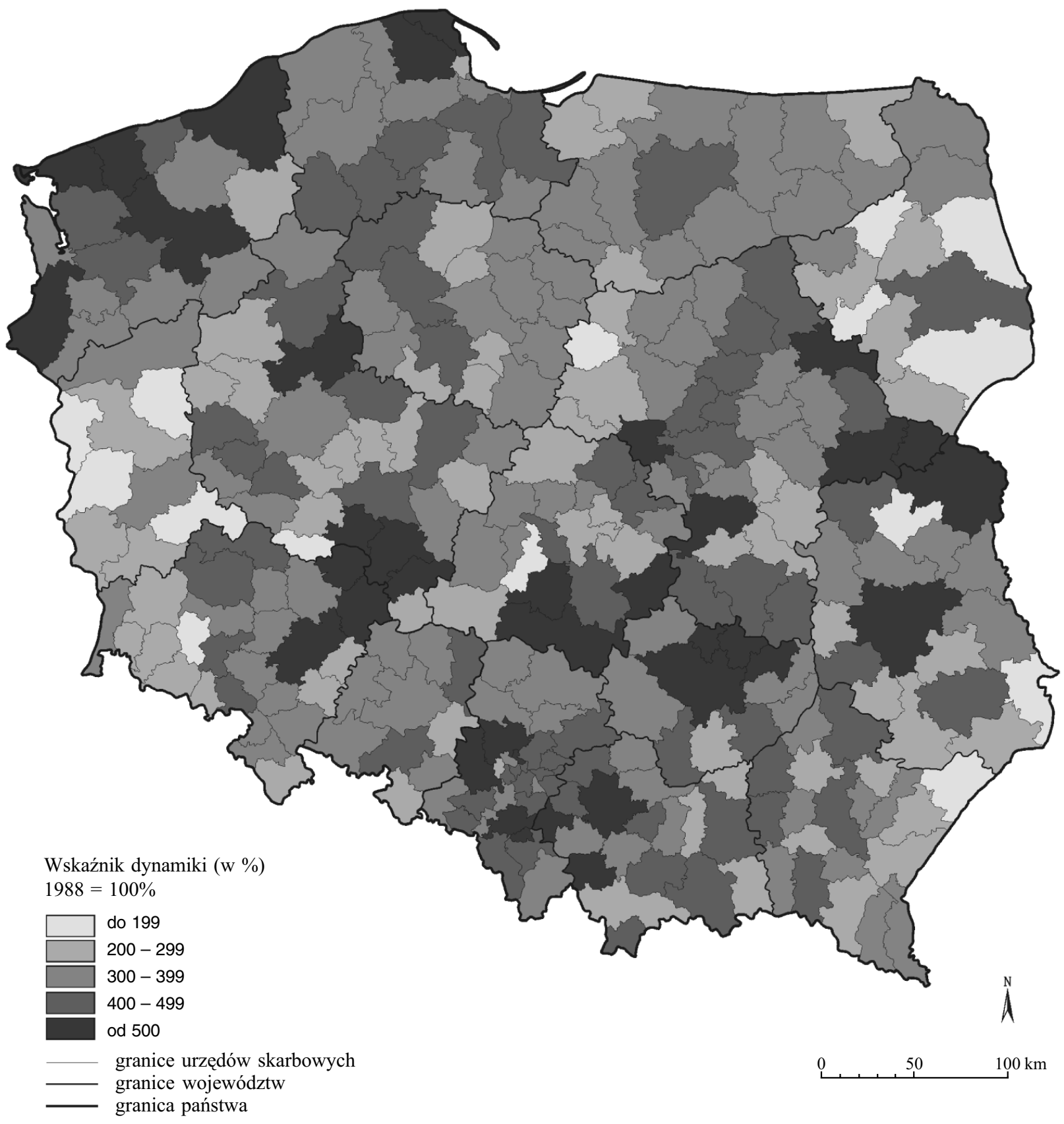

\section{Rozmieszczenie małych firm prywatnych w Polsce w 2004 r.}

W 2004 r. wskaźnik przedsiębiorczości wahał się od 26,8 do 217,7, przyjmując średnią wartość 69,5. W układzie przestrzennym stwierdzono, że (ryc. 4):

1. najwyższą koncentracją (powyżej 90 małych firm na 1000 mieszkańców) odznaczało się

19 badanych jednostek przestrzennych, w tym m.in. rejony:

a) położone w sąsiedztwie Warszawy (Otwock, Grodzisk Mazowiecki, Pruszków);

b) położone na obszarach atrakcyjnych turystycznie (Puck, Sopot, Świnoujście, Kamień Pomorski, Tczew, Zakopane, Bielsko-Biała); dodatkowo w rejonie puckim funkcjonuje Żarnowiecka Specjalna Strefa Ekonomiczna;

c) związane z wielkimi aglomeracjami: Warszawą, Poznaniem, Wrocławiem i Łodzią; 
2. wysokie wskaźniki przedsiębiorczości zanotowano również w rejonach położonych na południu Polski (w Zakopanem, Nowym Targu, Cieszynie, Kłodzku, Bystrzycy Kłodzkiej), które odznaczają się wysoką atrakcyjnością turystyczną i położeniem przygranicznym;

3. najniższe wskaźniki (do 30 zakładów na 1000 mieszkańców) stwierdzono głównie we wschodniej Polsce. Spośród 17 rejonów, 5 położonych było we wschodnim pasie (Opole Lubelskie, Leżajsk, Przeworsk, Kolbuszowa, Lubaczów).

Ryc. 4. Przestrzenne zróżnicowanie wskaźnika przedsiębiorczości w Polsce w 2004 r.

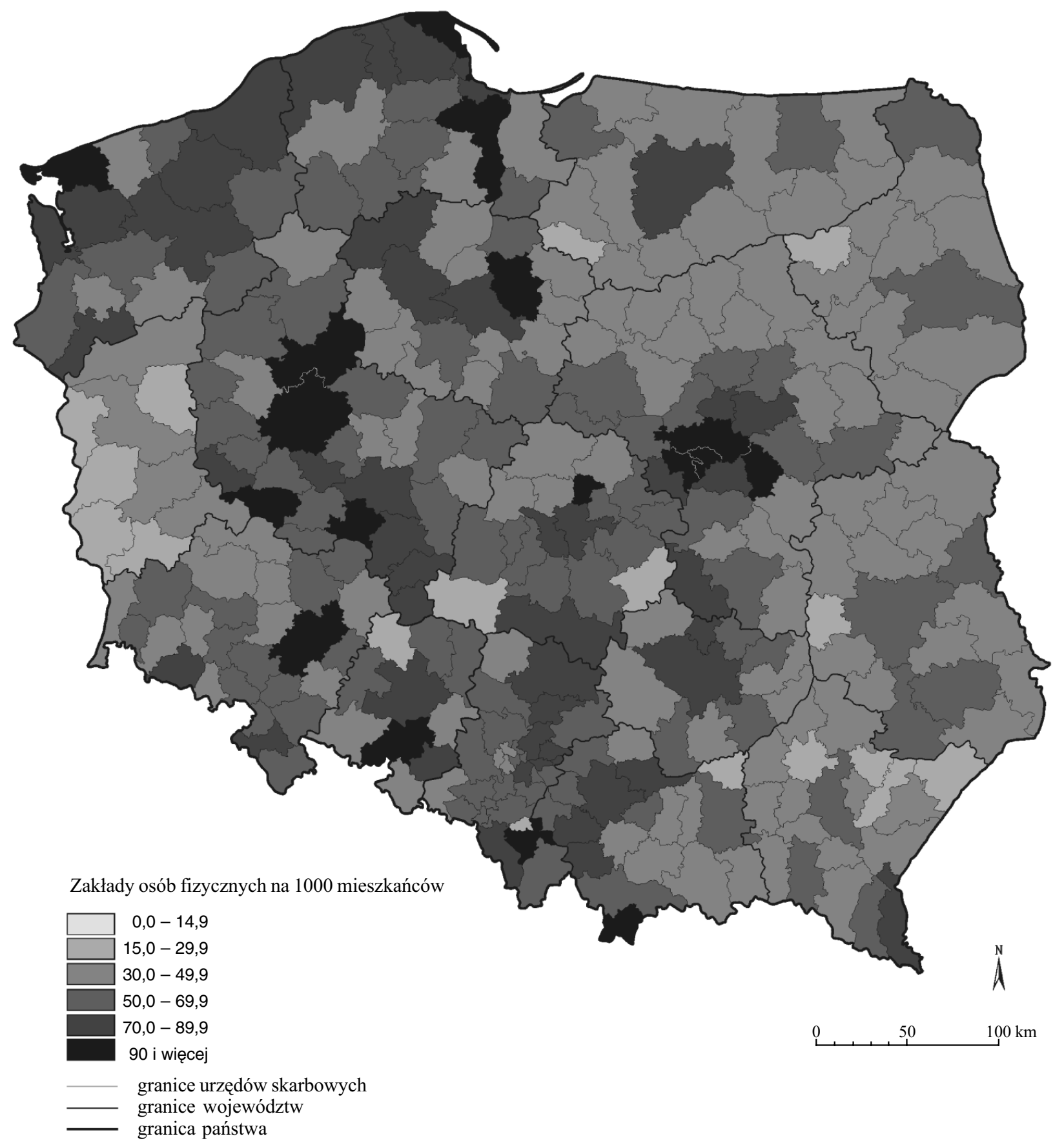

Rozkład małych prywatnych firm pokrywa się ze strefami atrakcyjności wyróżnionymi przez innych autorów (Gorzelak 1994; R. Domański 1997; Rykiel 1997; B. Domański i in. 2000; Czyż 2001; Nowosielska 2001). Najbardziej atrakcyjnymi lokalizacjami dla małych firm były 
wielkie aglomeracje miejsko-przemysłowe. Obok nich wyraźnie wyłaniają się dwie osie rozwoju: pierwsza ciągnąca się łukiem od rejonu gdańskiego przez bydgoski, poznański, wrocławski do krakowskiego; druga równoleżnikowa - rejony warszawski i łódzki. Na wschodnich obszarach peryferyjnych tylko Białystok i Lublin są atrakcyjne dla lokalizacji małych firm prywatnych.

\section{Zmiany struktury rodzajowej małych firm prywatnych w Polsce w okresie transformacji}

Badanie przemian struktury rodzajowej małych firm prywatnych w Polsce w latach 1991-2004 jest utrudnione w związku ze zmianą klasyfikacji działalności gospodarczej. W latach 1991-1995 w sprawozdawczości skarbowej obowiązywała Klasyfikacja Działalności Gospodarczej (KGN), a w latach 1996-1998 - Europejska Klasyfikacja Działalności (EKD), w której podmioty zostały skupione w sekcjach. Przemiany struktury działowej zostały zatem przedstawione dla dwóch klasyfikacji i dwóch okresów: lata 1991-1995 według KGN, a lata 1996-1998 według EKD.

Na ogólny wzrost liczby małych firm prywatnych w różnym stopniu wpłynęły zakłady reprezentujące poszczególne rodzaje działalności (tab. 3). W latach 1991-1995 najszybciej rozwijały się firmy świadczące usługi niematerialne. Ich liczba zwiększyła się ponaddwukrotnie (do 237,2\%). Drugą pozycję zajęły podmioty reprezentujące usługi materialne. Liczba zakładów wzrosła do 173,8\%. Mniej dynamicznie rozwijały się zakłady handlowe, gastronomiczne i transportowe. Wskaźnik dynamiki liczby zakładów wahał się od 148,6\% (transport) do 151,1\% (handel). Najwolniej rozwijały się zakłady budowlane (wskaźnik dynamiki 119,7\%). W tym okresie zaobserwowano spadek liczby zakładów przemysłowych do 93,8\%.

Tab. 3. Dynamika i przemiany struktury rodzajowej małych firm prywatnych w Polsce w latach 1991-1995

\begin{tabular}{|r|l|r|r|r|r|r|r|r|r|r|r|}
\hline \multirow{2}{*}{ Lp. } & \multirow{3}{*}{ Dzial } & \multicolumn{4}{|c|}{ Dynamika liczby zakladów } & \multicolumn{4}{c|}{ Struktura zakładów (w \%) } \\
\cline { 3 - 11 } & & 1991 & 1992 & 1993 & 1994 & 1995 & 1991 & 1992 & 1993 & 1994 & 1995 \\
\hline 1 & Przemysł & 100 & 99,4 & 99,0 & 92,3 & 93,8 & 24,6 & 21,3 & 19,4 & 17,1 & 16,2 \\
\hline 2 & Budownictwo & 100 & 109,5 & 114,2 & 115,2 & 119,7 & 12,1 & 11,5 & 11,0 & 10,5 & 10,1 \\
\hline 3 & Transport & 100 & 118,0 & 129,2 & 138,2 & 148,6 & 4,4 & 4,5 & 4,5 & 4,6 & 4,6 \\
\hline 4 & Handel & 100 & 113,8 & 128,9 & 139,4 & 151,1 & 38,8 & 38,4 & 39,7 & 40,8 & 41,1 \\
\hline 5 & Gastronomia & 100 & 129,5 & 139,2 & 143,4 & 150,6 & 2,7 & 3,0 & 2,9 & 2,9 & 2,8 \\
\hline 6 & Usługi materialne & 100 & 115,0 & 132,3 & 157,0 & 173,8 & 9,0 & 9,0 & 9,4 & 10,6 & 10,9 \\
\hline 7 & Usługi & 100 & 164,5 & 191,5 & 209,6 & 237,2 & 8,6 & 12,3 & 13,1 & 13,6 & 14,3 \\
& niematerialne & & & & & & & & & & \\
\hline & Razem & $\mathbf{1 0 0}$ & $\mathbf{1 1 4 , 8}$ & $\mathbf{1 2 5 , 8}$ & $\mathbf{1 3 2 , 6}$ & $\mathbf{1 4 2 , 5}$ & $\mathbf{1 0 0 , 0}$ & $\mathbf{1 0 0 , 0}$ & $\mathbf{1 0 0 , 0}$ & $\mathbf{1 0 0 , 0}$ & $\mathbf{1 0 0 , 0}$ \\
\hline
\end{tabular}

Źródło: opracowanie własne

W latach 1991-1995 najsilniej rozwijały się zatem te rodzaje działalności gospodarczej, których powstawanie w okresie gospodarki centralnie sterowanej było ograniczane (usługi materialne, usługi niematerialne, handel), natomiast rodzaje działalności dominujące do roku 1988 (przemysł, budownictwo) nie w pełni przystosowały się do nowych warunków gospodarowania i traciły na znaczeniu. 
Zróżnicowane tempo wzrostu poszczególnych rodzajów małych firm prywatnych wpłynęło na zmianę ich struktury działowej (tab. 3). W 1995 r. największe znaczenie miał handel. W latach 1991-1995 jego udział w strukturze zakładów wzrósł z 38,8\% do 41,1\%, tj. o 2,3 pp. Drugą pozycję zajęły podmioty przemysłowe, których udział zmniejszył się z 24,6\% do 16,2\%, tj. o 8,4 pp. Trzecie miejsce miały zakłady związane z usługami niematerialnymi; ich udział w strukturze wzrósł z 8,6\% do 14,3\%, tj. o 5,7 pp. Wymienione grupy podmiotów w końcu badanego okresu obejmowały łącznie 71,6\% ogólnej liczby zakładów kraju, a ich udział w stosunku do $1991 \mathrm{r}$. zmniejszył się o 0,4 pp. Pozostałe rodzaje podmiotów miały mniejsze znaczenie, a ich udział wahał się od 2,8\% (gastronomia) do 10,9\% (usługi materialne).

W latach 1996-1998 najsilniej rozwijały się firmy pośrednictwa finansowego. Ich liczba wzrosła aż do $182,6 \%$ (tab. 4). Wiązało się to z trwającą wówczas reformą ubezpieczeń.

Tab. 4. Dynamika i przemiany struktury małych firm prywatnych według sekcji EKD w Polsce w latach 1996-1998

\begin{tabular}{|l|r|r|r|c|r|r|r|}
\hline \multirow{2}{*}{ Sekcje } & \multicolumn{3}{|c|}{ Liczba zakładów (w tys.) } & $\begin{array}{l}\text { Dynamika } \\
\text { liczby zakladów } \\
(\mathbf{1 9 9 6 = 1 0 0 \% )}\end{array}$ & \multicolumn{3}{c|}{ Struktura zakładów (w \%) } \\
\cline { 2 - 9 } & 1996 & 1997 & 1998 & 1998 & 1996 & 1997 & 1998 \\
\hline $\begin{array}{l}\text { Rolnictwo } \\
\text { i leśnictwo (A,B*) }\end{array}$ & 20,6 & 25,7 & 28,9 & 140,3 & 1,0 & 1,2 & 1,3 \\
\hline Przemysł (C,D,E) & 281,6 & 277,0 & 283,3 & 100,6 & 13,6 & 12,9 & 12,4 \\
\hline Budownictwo (F) & 214,5 & 226,0 & 248,3 & 115,7 & 10,4 & 10,5 & 10,8 \\
\hline Handel i naprawy (G) & 927,8 & 945,9 & 986,1 & 106,3 & 44,8 & 44,0 & 43,1 \\
\hline $\begin{array}{l}\text { Hotele } \\
\text { i restauracje (H) }\end{array}$ & 60,7 & 63,3 & 68,1 & 112,2 & 2,9 & 2,9 & 3,0 \\
\hline Transport (I) & 165,7 & 180,8 & 194,2 & 117,2 & 8,0 & 8,4 & 8,5 \\
\hline $\begin{array}{l}\text { Pośrednictwo } \\
\text { finansowe (J) }\end{array}$ & 20,5 & 29,8 & 37,4 & 182,6 & 1,0 & 1,4 & 1,6 \\
\hline Usługi (K-O) & 380,5 & 399,8 & 443,5 & 116,6 & 18,4 & 18,6 & 19,4 \\
\hline Razem & $\mathbf{2 0 7 1 , 9}$ & $\mathbf{2 1 4 8 , 3}$ & $\mathbf{2 2 8 9 , 8}$ & $\mathbf{1 1 0 , 5}$ & $\mathbf{1 0 0 , 0}$ & $\mathbf{1 0 0 , 0}$ & $\mathbf{1 0 0 , 0}$ \\
\hline
\end{tabular}

* oznaczenia sekcji gospodarki narodowej

Źródło: opracowanie własne

W tym okresie dynamicznie rozwijały się także firmy reprezentujące rolnictwo, łowiectwo i leśnictwo oraz rybołówstwo i rybactwo. Liczba tych zakładów wzrosła do 140,3\%. Wolniej powstawały zakłady reprezentujące: budownictwo, transport, handel i naprawy, pozostałą działalność usługową oraz hotele i restauracje. Liczba zakładów w tej grupie wzrosła o 12-17\%. Firmy produkcyjne odznaczały się stagnacją, bowiem ich liczba wzrosła zaledwie o $0,6 \%$, a liczba w nich pracujących o $6,0 \%$.

W końcu 1998 r. w strukturze małych firm prywatnych dominujące znaczenie miały zakłady reprezentujące handel i naprawy. Stanowiły one aż 43,1\% ogólnej liczby małych firm prywatnych. Drugą pozycję miały usługi skupiające 19,4\% ogółu zakładów. Na trzecim miejscu znalazły się firmy przemysłowe (12,4\% zakładów). Wymienione rodzaje działalności w końcu $1998 \mathrm{r}$. skupiały łącznie 74,9\% małych prywatnych w Polsce. 


\section{Wnioski}

1. Badania wykazały, że prywatna działalność gospodarcza stała się ważnym elementem aktywizującym gospodarkę i łagodzącym społeczne skutki transformacji. W badanym okresie transformacji gospodarczej prawie wszystkie nowe miejsca pracy powstawały w sektorze prywatnym, w tym w małych prywatnych firmach. Podczas gdy w latach 1990-2004 w całej gospodarce narodowej liczba pracujących obniżyła się z 16,4 mln osób do 12,6 mln osób, tj. do 76,8\%, to w małych prywatnych zakładach powstało 2,9 mln nowych miejsc pracy. Pojawiło się pozytywne pod względem ekonomicznym i psychologicznym zjawisko samozatrudnienia.

2. Proces rozwoju prywatnej przedsiębiorczości przebiegał z różnym natężeniem w czasie i przestrzeni.

3. Potwierdzona została wyjątkowa atrakcyjność dla lokalizacji małych firm prywatnych Warszawy, obszarów położonych w jej sąsiedztwie oraz innych wielkich aglomeracji miejsko-przemysłowych.

4. Duża aktywność w tworzeniu małych firm prywatnych wystapiła także w rejonach o podwyższonej atrakcyjności turystycznej (np. w Zakopanem, Wejherowie). Jednak nie we wszystkich rejonach atrakcyjnych turystycznie wzrosła liczba takich zakładów (np. w Pieninach i na Pojezierzu Mazurskim). Przyczyną były niedorozwój infrastruktury turystycznej i słaba promocja tych obszarów.

5. Stosunkowo mało zakładów powstało w rejonach małych miast (poniżej 20 tys. mieszkańców). Są to głównie rozległe obszary wiejskie oraz małe miasta, zaliczane do głównych ,przegranych" w procesie transformacji.

6. Przemiany zachodzące w strukturze przestrzennej małych firm prywatnych prowadziły raczej do pogłębiania się regionalnych różnic niż do ich wyrównywania. Szczególnie wyraźne różnice wystąpiły między Polską zachodnią i centralną a Polską wschodnią oraz między obszarami miejskimi a obszarami wiejskimi.

7. Zmiany struktury przestrzennej małych firm prywatnych były spowodowane zróżnicowanym stopniem atrakcyjności (wyposażenia instytucjonalnego i społecznego) poszczególnych jednostek przestrzennych dla ich lokalizacji.

8. W okresie gospodarki centralnie sterowanej prywatna działalność gospodarcza była ustawowo ograniczana. Skutkiem tego było małe zróżnicowanie struktury rodzajowej tego typu zakładów w poszczególnych jednostkach przestrzennych.

9. W latach 1988-1995 najszybciej rozwijały się te rodzaje działalności gospodarczej, których rozwój w okresie gospodarki centralnie sterowanej był ograniczany (usługi materialne, usługi niematerialne, handel). Natomiast rodzaje działalności przeważające do roku 1988 (przemysł, budownictwo) nie w pełni przystosowały się do nowych warunków gospodarowania i traciły na znaczeniu.

10. Na kształtowanie się struktury rodzajowej małych firm prywatnych, oprócz czynników o zasięgu krajowym, w coraz większym stopniu miały wpływ czynniki regionalne i lokalne.

11. W latach 1996-1998 najszybciej rozwijały się podmioty reprezentujące pośrednictwo finansowe. Dynamicznie rozwijał się też cały sektor usług. Kierunek ten był zgodny z tendencjami obserwowanymi na zachodzie Europy.

12. Dalszy rozwój małych firm prywatnych w Polsce będzie zależeć głównie od polityki rządu wobec sektora małych przedsiębiorstw oraz warunków wynikających z przystąpienia Polski do Unii Europejskiej. Nie bez znaczenia pozostaną również przemiany demograficzne w kraju. 


\section{Literatura}

1. Czyż T., Zróżnicowanie regionalne Polski w układzie nowych województw [w:] T. Czyż (red.), Zróżnicowanie spoleczno-gospodarcze w nowym układzie terytorialnym Polski, „Biuletyn KPZK PAN”, Warszawa 2001.

2. Domański R., Przestrzenna transformacja gospodarki, PWN, Warszawa 1997.

3. Domański B., Guzik R., Gwosdz K., Konkurencyjność i ranga wielkich miast $w$ świetle inwestycji zagranicznych firm produkcyjnych [w:] R. Domański (red), Nowe problemy rozwoju wielkich miast i regionów, „Biuletyn KPZK PAN”, z. 192, Warszawa 2000.

4. Gorzelak G., Regionalne oblicze polskiej transformacji w latach 1990-2005 [w:] A. Mync, B. Jałowiecki (red.), Przedsiębiorczość i prywatyzacja, „Biuletyn KPZK PAN”, z. 168, Warszawa 1994.

5. Kamińska W., The development of the private micro-companies in the towns in south-east Poland in the years 1994-2003, „Geopolitical Studies”, vol. 12, Polish Academy of Sciences, Warsaw 2004.

6. Nowosielska E., Wielkie firmy ustugowe w układzie nowych województw [w:] T. Czyż (red.), Zróżnicowanie społeczno-gospodarcze w nowym uktadzie terytorialnym Polski, „Biuletyn KPZK PAN”, Warszawa 2001.

7. Piasecki B., Przedsiębiorczość i mała firma: teoria i praktyka, UŁ, Łódź 1997.

8. Rykiel Z., Relacje centrum-peryferie w Polsce w warunkach transformacji ustrojowej [w:] A. Kukliński (red.), Problematyka przestrzeni europejskiej, Europejski Instytut Rozwoju Regionalnego i Lokalnego, UW, Warszawa 1997.

9. Stryjakiewicz T., Adaptacja przestrzenna przemystu $w$ Polsce $w$ warunkach transformacji, UAM, Poznań 1999.

10. Targalski J. (red.), Przedsiębiorczość i rozwój firmy, AE, Kraków 1999.

\section{Influence of Transformation Processes on the Development of Small Private Companies in Poland}

The transformation of socioeconomic system in Poland started at the end of eighties of the $20^{\text {th }}$ century. Already existing political, social, economic and regional structures in the course of this process had changed. Changes in size and ownership structure of the business entities had been particularly extensive, what resulted in dynamic development of small companies and their significant market growth in the structure of the employed in the national economy from: $7,9 \%$ in the year 1988 , to $23,8 \%$ in 2004 . The process of changes in size and the ownership structure of the business entities had taken place upon various intensity of the time and place.

The goal of this article is to answer the following questions:

1. What are the regularities of development and transformation of spatial structure of small companies in the period of transformation in Poland?

2. What are the regularities of transformation of genre structure of small private companies during the transformation period in Poland?

3. What are the factors that influence upon the development of small private companies during the transformation period in Poland? 